\title{
Krzysztof Rudomin
}

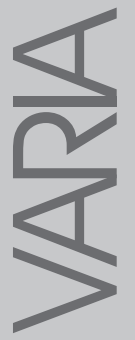

Krzysztof Rudomin - magistrant filologii polskiej ze specjalizacją filmoznawczą na Uniwersytecie Mikołaja Kopernika w Toruniu. 


\title{
„It's alive!” - mocno subiektywnie o „ożywianiu” Grabińskiego w mediach kultury współczesnej
}

Stephen King pisze o horrorze:

\begin{abstract}
Gatunek, o którym mówimy, niezależnie od tego, czy mamy na myśli książki, filmy czy programy telewizyjne, jest $w$ istocie tylko jednym: pełnym grozy zmyśleniem. A jedno z najczęściej pojawiających się pytań, zadawanych przez ludzi, którzy dostrzegli istnienie tego paradoksu (choć może nie wyartykułowali go w pełni w swych umysłach), brzmi: po co wymyślać nowe upiory, skoro i tak nasz świat pełen jest strachu?

Można na to odpowiedzieć następująco: wymyślamy nowe strachy po to, by pomogły nam rozprawić się z prawdziwymi zagrożeniami. Postawieni w obliczu nieskończonej ludzkiej wynalazczości, staramy się wyłapać z niej najważniejsze, najbardziej destrukcyjne elementy i przetworzyć je w narzędzia, które zwrócimy przeciw nim samym .
\end{abstract}

Trudno się z Kingiem nie zgodzić. Od czasu powstania Danse macabre minęło kilkadziesiąt lat, a świat napełnia się wciąż nowymi strachami. W czasach młodości autora straszyli go (jak i w jego przekonaniu cały naród amerykański) Rosjanie swoim Sputnikiem, przerażała wojna w Wietnamie, szokowało zabójstwo Kennedy’ego. Dziś, globalnie jesteśmy straszeni rychłą apokalipsą, czy to naturalną, czy spowodowaną wojną nuklearną, zamachami terrorystycznymi lub różnego rodzaju światowymi kryzysami.

„Groza - to co Hunter Thompson nazywa «strachem i obrzydzeniem» - często powstaje w wyniku powszechnej dezintegracji, wrażenia, że rzeczy wokół zaczynają się rozpadać”2. Jak reagujemy na ów rozpad dzisiaj, w świecie, który jest - paradoksalnie - jednocześnie niepokojący, przesycony „dzianiem się”, nakazującym w nienaturalny sposób przyswajać

\footnotetext{
1 S. King, Danse macabre, tłum. P. Braiter, P. Ziemkiewicz, Warszawa 2005, s. 36.

2 Ibidem, s. 30.
} 
coraz więcej informacji i w swym kulturowo-technicznym pędzie podlegający nieustannym przemianom, ale też w wielu sferach „coraz bardziej urzeczowiony, przejrzysty, obliczalny, przewidywalny, a przez to mniej «magiczny»", "odczarowany”?

Dzisiejsza filmowa czy literacka groza opiera się na - pozwolę sobie uogólnić, nie zapominając o wyjątkach od reguly - ukazywaniu przemocy i makabry, badaniu granic ludzkiego bólu oraz tworzeniu coraz bardziej wymyślnych w swej obrzydliwości i krwiożerczości stworów (którymi notabene najczęściej jest spaczony, zdegenerowany człowiek). Jednostka ludzka stała się w horrorach jeśli nie narzędziem, to przynajmniej statystą. Nie chodzi o to, iż została całkowicie pozbawiona emocji i duszy, lecz o to, że człowiecze pierwiastki zostały do granic możliwości zredukowane.

Groza, wyłączając filmy katastroficzne i tego typu literaturę, coraz mniej zawiera w sobie tematów ogólnoludzkich, jest coraz bardziej wulgarna w swej dosłowności i nie ma w niej miejsca na umieszczenie czynników oczyszczających, tych ukrytych treści, których odbiorca z przyjemnością odczuwania strachu domyślałby się.

Czy właśnie dlatego da się dzisiaj zaobserwować boom na grozę w stylu retro? Na grozę, która, niczym filmy Murnaua, Wegenera czy Langa, nie pozwala na ukazanie pełnego ludzkiego zezwierzęcenia (jest ono najwyżej zawoalowane) i która pod maskami potworów przemyca obraz człowieka ze wszystkimi jego słabościami, osadzonego w zdeformowanej lub zhipertrofizowanej przestrzeni, będącej oczywistą metaforą świata lub kształtujących go wydarzeń realnych? Czy dlatego czytelnicy (ale i twórcy - pisarze, reżyserzy, muzycy) coraz częściej przypominają sobie o Poem, Stokerze czy Mary Shelley?

Wspomniane zezwierzęcenie oraz nieustanną eskalację przemocy i makabry codziennie pokazują nam wiadomości medialne i ulice. Nie sposób się dziwić, że nastąpiło „zmęczenie materiału”. Odbiorcy kultury grozy chcą wreszcie zastąpić krwawą rozrywkę strachem zmuszającym do myślenia i tym samym przełamać wszechogarniający defetyzm. Konsumenci horroru chcą się dziś bać duchowo, a nie instynktownie, ponieważ strach instynktowny odczuwają na co dzień. Chcą się dziś bać mądrze i z klasą, mieć ze strachu pożytek, dzięki niemu się rozwijać. Potrzebują katharsis poprzez grozę, a nie obciążenia makabrycznym obrazem.

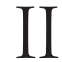

Twórczość Stefana Grabińskiego przeżywa w ostatnich kilku latach prawdziwy renesans temu nie da się zaprzeczyć. Autor za życia niedoceniany, dzisiaj często stawiany jest przez miłośników literatury grozy, przynajmniej w Polsce, na jednej linii z takimi klasykami, jak Edgar Allan Poe i Howard Phillips Lovecraft.

Internetowe uniwersum zaroiło się od lepszych czy gorszych stron poświęconych polskiemu Poemu. Jest to zjawisko, trzeba przyznać, dość zaskakujące. Ciekawe, czy Grabiński, gdyby żył dzisiaj, założyłby swój facebookowy profil? Gdybanie gdybaniem - Grabiński takowy ma, czyby tego chcial, czy nie ${ }^{4}$.

\footnotetext{
3 M. Punpur, Racjonalizacja, odczarowywanie świata, a problem legitymizacji władzy, http://www.racjonalista.pl/kk.php/s,5813 [dostęp: 18.03.2012].

4 Adres profilu aktualny 22.03.2012: http://www.facebook.com/pages/Stefan-Grabinski/104187931790. Grabiński posiada nie tylko swój profil facebookowy. Jak przystało na klasyka (nie ominęło to bowiem i Poego,
} 
$\mathrm{Z}$ autorem tym zetknąłem się przypadkiem dawno temu. Kierowany dziecięcą ciekawością penetrowałem biblioteczkę dziadków na poddaszu. Tam właśnie znalazłem i przywłaszczyłem sobie między innymi dwa tomy opowiadań Edgara Allana Poego, wydane w 1986 roku w Warszawie i mocno podniszczony zbiorek opowiadań Grabińskiego - część drugą Niesamowitych opowieści wydawnictwa Iskry z 1981 roku. W wiele lat później, będąc już czytelnikiem w jakimś stopniu świadomym i ukształtowanym, przypomniałem sobie o Grabińskim i zacząłem poszukiwania innych jego utworów. W niektórych bibliotekach można było wypożyczyć trzytomowy zbiór Artura Hutnikiewicza, doskonale znany zainteresowanym. Gorzej rzecz się miała z Namiętnościami: opowieścia wenecką. Do dzisiaj zetknąłem się z jednym egzemplarzem, wydanym w roku 1930. Zbiór nie został od tamtej pory wznowiony w całości.

Minęło pierwsze dziesięciolecie XXI stulecia. Może za sprawą 125. rocznicy urodzin Grabińskiego, może ze względu na wygaśnięcie praw autorskich do jego dzieł i może za sprawą inicjatywy przemyskiego środowiska naukowego oraz grupy miłośników twórczości polskiego klasyka grozy zaczyna się istne wydawnicze szaleństwo z Grabińskim w roli głównej.

We wrześniu 2011 roku wydawnictwo Zysk i S-ka wydaje zbiór Demon ruchu i inne opowiadania (w niezbyt „demonicznej” oprawie, ale zawsze). XLVII „Rocznik Przemyski” (zeszyt 2 z 2011 roku) w dużej części poświęcony jest Stefanowi Grabińskiemu. Ukazał się także zbiór rozproszonych tekstów polskiego Poego, zatytułowany Wichrowate linie (tak nazywała się książka Szygonia, bohatera opowiadania Demon ruchu), za który odpowiedzialne jest wydawnictwo Agharta. To samo wydawnictwo prezentuje pierwsze powojenne wznowienie powieści kaszubskiej Klasztor i morze, która pierwotnie zaprezentowana została w 1928 roku. Również Agharta wydaje Tragedię na wieży. Opowieści nadzwyczajne - wybór opowiadań Grabińskiego i Jana Huskowskiego. Mamy także antologię wydawnictwa Kabort pod tytułem Demony perwersji, z tekstami Poego, Meyrinka, Ewersa i Grabińskiego. Jest to swoiste uzupełnienie antologicznej trylogii, wespół z dwiema częściami Maski śmierci.

Jak widać, miłośnicy Grabińskiego obsypywani są ostatnio bogactwem tekstów. A to przecież tylko niewielka część: pominąłem liczne publikacje naukowe (jak na przykład Fantazmaty: Grabiński - Prus - Zapolska Krystyny Kłosińskiej) i niektóre wydawnictwa wcześniejsze (wśród nich m.in. zbiór Demon ruchu z roku 1999, pierwszą powojenną edycję od 1922 roku, która - moim zdaniem - jest zupełnie nieudana pod względem edytorskim).

Co ciekawe, za tłumaczenie Grabińskiego wzięli się również nasi sąsiedzi z Czech. Za przekład zbioru opowiadań odpowiedzialny jest Libor Martinek ${ }^{5}$.

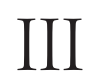

Grabiński opanowuje wydawnictwa i portale internetowe. Jeśli chodzi o te ostatnie, prym wiedzie Carpe Noctem. Ten portal związany z ogólnie pojmowaną tematyką grozy patronu-

i Lovecrafta, i innych wielkich, nieżyjących już twórców), ma również konto w serwisie myspace [sic!]: http:// www.myspace.com/stefangrabinski [dostęp: 22.03.2012]. Obie strony prowadzone są w języku angielskim.

5 Więcej szczegółów w wywiadzie z Liborem Martinkiem na stronie stefangrabinski.pl pod adresem: http://stefangrabinski.pl/publicystyka/wywiad-z-liborem-martinkiem/ [dostęp: 18.03.2012]. 
je zresztą większości wydawanych pozycji z nazwiskiem Grabińskiego zarówno na pierwszym planie, jak i w tle. Obejmuje również pieczę nad znaczną częścią imprez okolicznościowych i współpracuje z przemyskimi (i nie tylko) badaczami twórczości autora Salamandry.

Za sprawą Carpe Noctem powstała strona internetowa poświęcona wyłącznie Grabińskiemu i wydarzeniom związanym z jego osobą. Znajdziemy tam biografię i wyczerpującą bibliografię, teksty publicystyczne oraz informacje o projekcie GRoza, GRoteska, GRabiński' . Przeczytamy nawet wywiad z ... samym Grabińskim! To wywiad pośmiertny, a odpowiedzi polskiego Poego zbudowane zostały z jego prawdziwych cytatów.

Przemyśl, jedyne miasto na dzisiejszym terytorium Polski, w którym żył Grabiński, z powodzeniem promuje twórczość autora Demona ruchu. Przygotowywane są pokazy filmów na podstawie jego literackich dokonań, konferencje naukowe czy luźne pogadanki. Jest to swojego rodzaju pośmiertne zrekompensowanie Grabińskiemu dość chłodnego i obojętnego traktowania jego artystycznych dokonań przez przemyską społeczność.

Tomasz Pudłocki konstatuje:

Portal „Horror Online” tak pisze o Grabińskim: „Praca nauczyciela działała na niego wyniszczająco, potęgowała to jeszcze odziedziczona gruźlica, która stopniowo siała coraz większe zniszczenie w jego organizmie. Jego przyjaciel Karol Irzykowski pisał, iż Grabiński świadom śmiertelnej choroby zawczasu zaczął penetrować zaświaty. I tak w 1918 roku ukazał się zbiór Na wzgórzu róż. Nie wzbudził on jakiegoś szczególnego poruszenia, ale został ciepło przyjęty i Grabiński pierwszy raz doświadczył uczucia (skromnego, ale zawsze) sukcesu. Spowodowało to nagłą powódź pomysłów".

Warto dodać, pomysłów - dużo cieplej przyjętych w Polsce niż w Przemyślu, w którym wówczas Stefan Grabiński mieszkał.

Po prawie stu latach, kiedy grupa wielbicieli jego twórczości próbuje przywołać pamięć pisarza w 125. rocznicę jego urodzin, z większym zrozumieniem spotyka się w Krakowie, Katowicach, Toruniu niż... w jedynym mieście na dzisiejszym terytorium Polski, w którym mieszkał polski Poe $^{7}$.

Powróćmy do śledzenia internetowego „życia po życiu” Stefana Grabińskiego. Spośród całej masy stron zupełnie amatorskich i tych aspirujących do miana profesjonalnych, wybrałem (prócz wspomnianych dotąd) cztery, jak sądzę, najbardziej interesujące i przydatne.

\section{http://www.latarnia.com/stefangrabinski.html}

Strona anglojęzyczna, która zaintrygowała mnie nieznanymi mi dotąd faktami dotyczącymi współczesnego, wydawniczo-kinowego życia twórczości Grabińskiego. Z ciekawostek - Grabiński wielokrotnie wydawany był w języku angielskim. Warto wspomnieć choćby o The Motion Demon (2005, 2011), The Dark Domain (1993) i planach wydawniczych związanych ze zbiorami On The Hill of Roses i The Book of Fire. Wszystkie dotychczasowe i planowane publikacje są owocem pracy translatorskiej mieszkającego obecnie w Nowym Jorku Mirosława Lipińskiego.

\footnotetext{
${ }^{6}$ Link do części facebookowej poświęconej projektowi: http://www.facebook.com/pages/GRoza-GRoteska-GRabi\%C5\%84ski/333571883336388 [dostęp: 22.03.2012].

7 T. Pudłocki, „Przedzierając się” do opinii powszechnej z Grabińskim, http://stefangrabinski.pl/publicystyka/przedzierajac-sie-do-opinii-powszechnej-z-grabinskim [dostęp: 19.03.2012]. Artykuł dostępny również W "Naszym Przemyślu" 2011, nr 1, s. 31.
} 
Ze strony tej pochodzą również informacje o filmach będących bardziej lub mniej dokładnymi adaptacjami dzieł Grabińskiego bądź jedynie nimi inspirowanych. A od roku 1927, kiedy to powstał film Kochanka Szamoty w reżyserii Leona Trystana, wcale niemało powstało takich obrazów. Lata 1967 i 1968 przynoszą kolejno Ślepy tor i Pożarowisko, oba filmy w reżyserii Ryszarda Bera. W 1985 powstaje Dom Sary (reż. Zygmunt Lech), na podstawie opowiadania $W$ domu Sary. W tymże roku ten sam reżyser prezentuje Problemat profesora Czelawy (na podstawie Problematu Czelawy). W rok później powstaje obraz pod tytułem Nikt nie jest winien (reż. Ryszard Zatorski, na motywach Willi nad morzem), ze świetną według mnie rolą nieżyjącego już Marka Walczewskiego. W dwanaście lat później, bo w roku 1998, Joseph Parda reżyseruje Szamota's Mistress (oczywiście na podstawie Kochanki Szamoty). Holger Mandel adaptuje w 1999 i w 2001 roku kolejno Kochankę Szamoty (Szamotas Geliebte) i Ultima Thule. I na koniec, w roku 2011, Tomasz Budzyński i Łukasz Jankowski motywy opowiadania Maszynista Grot przenoszą na celuloid pod nazwą Podróż na Wschód.

\section{http://www.mpzabik.republika.pl/}

Prosta acz przydatna strona, zawierająca m.in. kilka opowiadań oraz skan Engramów Szatery z dodatku do „Tygodnika Powszechnego” - „Naokoło Świata” i elektroniczną wersję Z mojej pracowni. Opowieść o „Maszyniście Grocie”, zamieszczoną swego czasu w „Skamandrze”, a dostępną dzięki projektowi Cyfrowa Kolekcja Czasopism Polskich. Mnie najciekawsze wydały się jednak ilustracje Ryszarda Wojtyńskiego do prozy polskiego Poego.

\section{http://www.literat.ug.edu.pl/grabin/index.htm}

Strona opracowana przez Marka Adamca, zawierająca biogram i 11 nowel z różnych zbiorów.

http://www.elektury.org/authors/grabinski/grabinski.php Pod tym adresem znajdują się aż 42 nowele Stefana Grabińskiego.

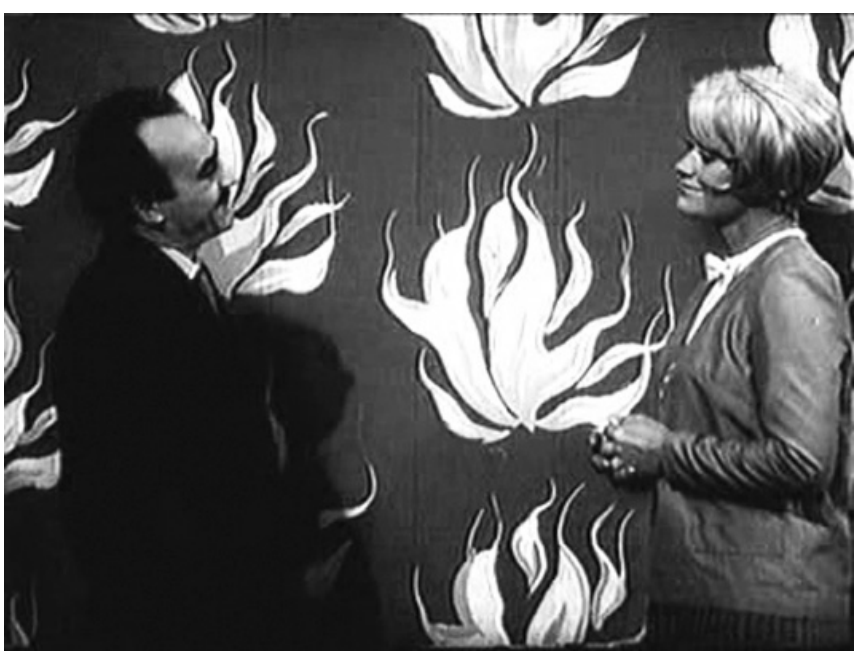

Kadr z filmu Pożarowisko,

reż. Ryszard Ber, 1968 


\section{IV}

Po zastanowieniu trzeba jednak przyznać, że Grabiński nie „oży” nagle w XXI wieku, ale próby jego „wskrzeszania” byly prowadzone od dawna.

Polski Poe, czy rzadziej - polski Lovecraft, nie mógł pojawić się na ekranie, dopóki nie zostało wynalezione kino. Nie było stron internetowych mu poświęconych, póki nie wymyślono Internetu itd. Grabiński, jak na klasyka przystało, musi zaistnieć wszędzie tam, gdzie można znaleźć odbiorców, bez względu na kanał komunikacji. To zjawisko naturalne. Książka tradycyjna, ebook, audiobook, film, czekać tylko na gry komputerowe (jak na przykład Call of Cthuhlu: Mroczne zakątki świata na podstawie twórczości Lovecrafta).

Na pewno wszystko to wskazuje, że Grabiński jest coraz bardziej doceniany, dociera do coraz większej liczby odbiorców i - co za tym idzie - można na nim coraz więcej zarobić. Jednak co za dużo, to niezdrowo - również jeśli chodzi o Grabińskiego. Autor, który pośmiertnie zdobył sobie jako taką sławę i poważanie, powinien teraz zza grobu tę sławę i poważanie trzymać w cuglach, by nie dać się skomercjalizować, dotknąć kiczem, poddać dyletantom, a pomogą mu w tym zapewne rzesze prawdziwych pasjonatów i rzetelnych badaczy ${ }^{8}$.

Stefan Grabiński dzisiejszą popularność zawdzięcza wciąż aktualnej uniwersalności swoich utworów, przejawiającej się tym, iż zarówno zwykli odbiorcy, jak i badacze literatury mogą czuć się usatysfakcjonowani bogactwem problematyki, znaczeń i odniesień.

Miłośników teorii psychometrycznych zainteresują utwory Szalona zagroda, Świadek Materna lub Szary pokój. Jeśli chodzi o „zaraźliwość” zła, w grę wchodzi również analiza przez pryzmat jungowski. Wątki psychometryczne we współczesnej literaturze grozy reprezentuje chociażby powieść Ciemność Jamesa Herberta. Co ciekawe, Herbert jako motta do każdej z części książki używa cytatów biblijnych. Twórczość Grabińskiego również okraszana jest biblijnymi fragmentami (Kochanka Szamoty, $W$ domu Sary). Badaczom wątków religijnych w literaturze utwory Grabińskiego zdają się wręcz narzucać. Obok Grabińskiego na pewno nie przejdą obojętnie filmoznawcy (o filmowych dziełach na podstawie twórczości Grabińskiego wspomniałem wcześniej). Również praktykujący gender studies nie powinni być rozczarowani rozległością pola interpretacyjnego otwierającego się w twórczości autora Salamandry.

\footnotetext{
8 Pisząc te słowa, mam na myśli m.in. odpowiedź Michała Budaka na artykuł Krzysztofa Vargi Powrót Grabińskiego, czyli duchy polskie z "Gazety Wyborczej" (6.10.2011). Budak uważa, iż tekst Vargi jest tendencyjny, ignorancki i nieprofesjonalny. Jeśli musiałbym opowiedzieć się po którejś ze stron, poparłbym bez namysłu Budaka. Dodam, że Varga opatrzył posłowiem (które, łagodnie mówiąc, również nie rzuca na kolana) krytykowanego przeze mnie pod kątem edytorskim Demona ruchu. Artykuł Vargi znaleźć można pod adresem: http://wyborcza.pl/1,99494,10424120,Powrot_Grabinskiego__czyli_duchy_polskie.html [dostęp: 22.03.2012], a odpowiedź Michała Budaka: http://stefangrabinski.pl/publicystyka/polemika-z-krzysztofem-varga/ [dostęp: 22.03.2012].
} 


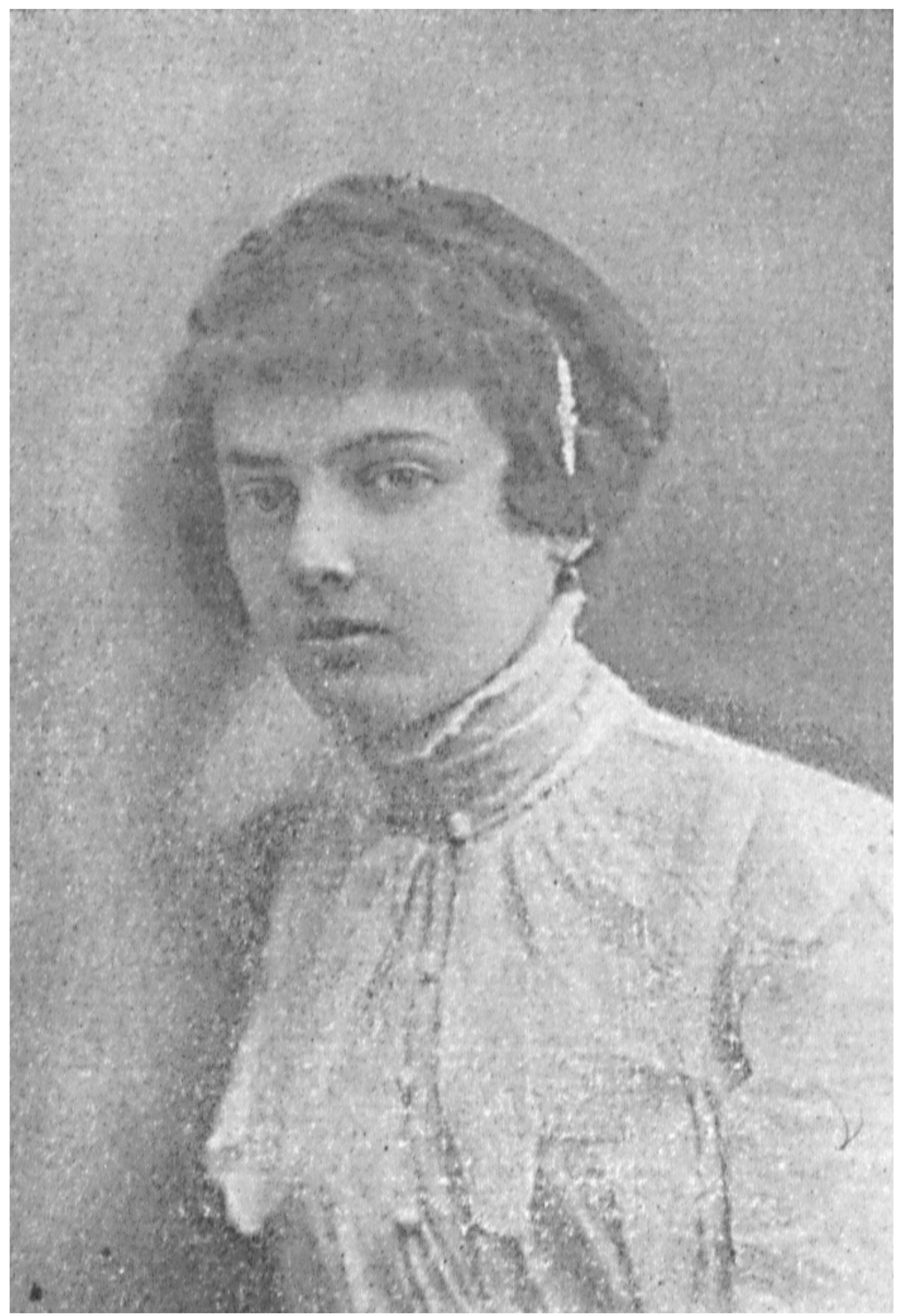

Maria z Grabińskich

Czajkowska (1892-1918),

jedna z dwóch młodszych

sióstr pisarza

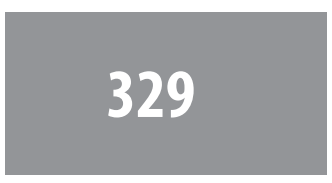

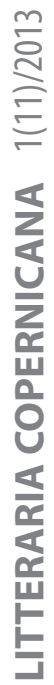


W tekstach Grabińskiego „marzenie wchłania samą rzeczywistość”. Jesteśmy przekonani, „że wyobraźnia jest w stanie «uczynić, że stwarzamy to, co widzimy»”10. Dlaczegóżby więc nie badać polskiego Poego także w kontekście poetyki marzenia? Szukając dalszych propozycji: jakże przystające do idei znacznej części dzieł Grabińskiego (choćby w Maszyniście Grocie albo Gtuchej przestrzeni) są filozoficzne teorie Maeterlincka w Życiu przestrzeni: „Ludzie ci, którzy na ziemi nam wydają się zmarłymi, żyją dalej w przestrzeni, czyli czasie przestrzennym, a ich istnienie, to znaczy teraźniejszość, przedłuża się tak dalej w nieskończoność, której krańców nie dosięgną nigdy, tak że to, co nie istnieje już w czasie, trwa dalej w przestrzeni, która, jak widzieliśmy, jest tylko innym aspektem czasu"11 i potem rozważania na temat czwartego wymiaru, czym Grabiński musiał się interesować. Samo wprost wypowiedziane pojęcie „wymiaru czwartego” pojawia się choćby w Engramach Szatery („Zdarzenia rzeczywiste rozegrawszy się na arenie świata widzialnego prawdopodobnie wsiąkają w przestrzenie wymiaru czwartego, by tu utrwalić swój obraz na kliszy astralnej”"12), w Salamandrze („Więc wyobraź sobie np., że byłeś przez trzy godziny w tzw. czwartym wymiarze zaludnionym chwilowo przez Kamę niektórymi elementami mojego domu” (S, s. 44-45)) albo w Sygnałach („Naczelnik, niestety, wkrótce potem zwariował i wszelkie próby wydobycia zeń prawdy spełzły na niczym; obłąkaniec zabrał ze sobą klucz do tajemnicy. Chyba przypadek zdarzy, że ktoś trafi na właściwe znaki i wywabi pociąg z czwartego wymiaru na ziemię"13).

Grabiński, niczym romantycy i dekadenci, w swoich dziełach zazwyczaj łączy piękno ze smutkiem i cierpieniem. Praz pisze, że Śmierć i Piękno byly „[... ] w oczach romantyków siostrami tak dalece, że zlały się w jedną o dwu obliczach rzeźbę piękna fatalnego, splamionego zepsuciem i melancholią, piękna, z którego tym obficiej tryska rozkosz, im więcej jest goryczy w jego smaku"14. I u polskiego klasyka grozy siostry owe kroczą pod rękę przez kolejne strony jego powieści i opowiadań, prawie każde kobiece piękno lączy bowiem, zdaje się wręcz automatycznie ze śmiercią albo chociażby demonicznością (Sara, Jadwiga, Kama, Nuna itd.).

Możliwości interpretacyjnych Grabiński dostarcza mnóstwo i wymieniać je można, zapełniając następne strony. To najpewniej kolejna przyczyna tłumacząca, dlaczego urodzony w Kamionce Strumiłowej autor przeżywa obecnie swój mały renesans. Najprościej rzecz ujmując - twórczość Stefana Grabińskiego, w porównaniu z bardziej popularnymi i eksploatowanymi „akademickimi” autorami, jest atrakcyjna ze względu na stosunkowo niewielki stopień rozpoznania.

\section{VI}

Horror to gatunek w Polsce zaniedbany. Najpewniej taki stan rzeczy ma podłoże historyczne. Polacy musieli bać się rzeczywistości i jeśli chodzi o dzieła literackie, zajmować się rzeczami „poważnymi” oraz aktualnymi. Można byłoby częściej w tym kontekście rozprawiać nad literaturą bardziej niepokoju niż grozy.

\footnotetext{
9 G. Bachelard, Poetyka marzenia, tłum., oprac., posłowiem opatrzył L. Brogowski, Gdańsk 1998, s. 22.

10 Ibidem, s. 23.

11 M. Maeterlinck, Życie przestrzeni, tłum. F. Mirandola, przedm. S. Błachowski, Poznań 1929, s. 169-170.

12 S. Grabiński, Engramy Szatery, [w:] idem, Demon ruchu, posł. K. Varga, Warszawa 1999, s. 128.

${ }^{13}$ Idem, Sygnały, [w:] S. Grabiński, Demon ruchu, s. 71.

14 M. Praz, Piękno Meduzy, [w:] idem, Zmysły, śmierć i diabeł w literaturze romantycznej, tłum. K. Żaboklicki, wstęp M. Brahmer, Warszawa 1974, s. 45.
} 
Sytuacja powoli się zmienia. Fakt, że względną popularnością cieszą się książki autorów takich, jak Pilipiuk, Cichowlas, Kyrcz Jr, Orbitowski, i wzrasta zainteresowanie klasykami pokroju Lovecrafta czy Poego, może napawać optymizmem. Do tego dochodzi ogromna ostatnimi czasy liczba wydawanych książek współczesnych autorów zagranicznych, jak Masterton, Koontz, nie wspominając o Stephenie Kingu, zdającym się być poza zasięgiem wszystkich innych twórców horroru. Z popularnością Kinga niekiedy wiążą się dość zabawne sytuacje. Często bywam świadkiem sceny, kiedy to klient, pytając w księgarni o jego najnowszą książkę, ma na myśli tytuł zupełnie inny niż sprzedawca, który z kolei nie ma świadomości, iż i on nie jest, jak to mu się do tej pory wydawało, na bieżąco z wydawniczymi informacjami i w bogactwie publikacji umknęły mu dwa tytuły najnowszych powieści i trzy wznowienia opowiadań współczesnego króla horroru.

Wracając do Grabińskiego, mam nadzieję, że takie sytuacje akurat tego autora dotyczyć nie będą. Bo o ile King żyje i tworzy, i da się zrozumieć jego literacką płodność, to Grabiński, co oczywiste, nic już nie napisze, chyba że zza grobu, bo przecież w życie pozagrobowe i kontakt świata zmarlych z tym światem wierzył.

A teraz już zupełnie poważnie. O ile jeszcze niedawno domagałem się więcej Grabińskiego „dzisiaj”, tak dziś mam nadzieję, iż nie będzie go zbyt wiele „jutro”. Niestety, tytuły poszczególnych jego opowiadań irytująco powtarzają się w kolejnych zbiorach i antologiach, nie zawsze zresztą z dostateczną dbałością wydanych.

Tekstom naukowym powiedzieć trzeba zdecydowane „tak”. Publikacja zbioru prac na temat twórczości Grabińskiego, w moim mniemaniu, jest o wiele bardziej pożądana (przede wszystkim pożyteczna) niż kolejny Demon ruchu z licznymi błędami czy też opracowany graficznie tak, iż ilustracje do niego mogłyby zostać umieszczone najwyżej w książeczce dla dzieci do lat siedmiu, zawierającej Lokomotywę Tuwima.

No właśnie. To, że o twórczości Grabińskiego, o jego duchu w XXI wieku można powiedzieć na wzór Frankensteina „It's alive!”, oznacza nie tylko zapotrzebowanie na „mądrą" grozę, potrzebę oczyszczenia przez strach w reakcji na dezintegrację zastanego świata, o czym wspomniałem na początku. Oznacza to nie tylko (wreszcie) docenienie znakomitego przecież autora i troskę o podtrzymanie pamięci o nim, i nie tylko działalność pasjonatów oraz badaczy. Sytuacja ta mówi również wiele o czasie, w którym żyjemy. Otóż wszystko jest na sprzedaż. Nawet z Grabińskiego można zrobić produkt i eksploatować go dotąd, dokąd będzie przynosił zysk.

Podsumowując - i naiwnie, acz z wielką wiarą zapominając na moment w zakończeniu o ekonomicznym przyczynku do popularności twórczości polskiego klasyka grozy we współczesnych mediach kultury - przytoczę słowa samego Grabińskiego z fikcyjnego wywiadu prowadzonego przez Michała Budaka. Czy dojrzeliśmy do odbioru horroru? Czy $\mathrm{w}$ realiach pozbawionych fantastyczności pragniemy fantastyki? Czy chcemy, co wybrzmiało już na początku tekstu, grozy „ludzkiej”, wyższej niż kinowe krwawe jatki, które można byłoby oglądać bez głowy, gdyby oczy rosły na przykład na dłoni? A może wszystko naraz? W kontekście poniższych słów zjawisko „ożywiania” Grabińskiego najlepiej tłumaczy chyba przesyt spowodowany konsumpcjonizmem, pozbawienie jednostki intymności i moda na bezrefleksyjne, często pozowane na hiperoptymistyczne życie. Zresztą - niech każdy sam spróbuje sobie odpowiedzieć, dlaczego właśnie dziś ucieczka w grabińszczyznę i sięganie po nią w różnych celach jest tak częstym zjawiskiem. 
Kadr z filmu Ślepy tor,

reż. Ryszard Ber, 1967

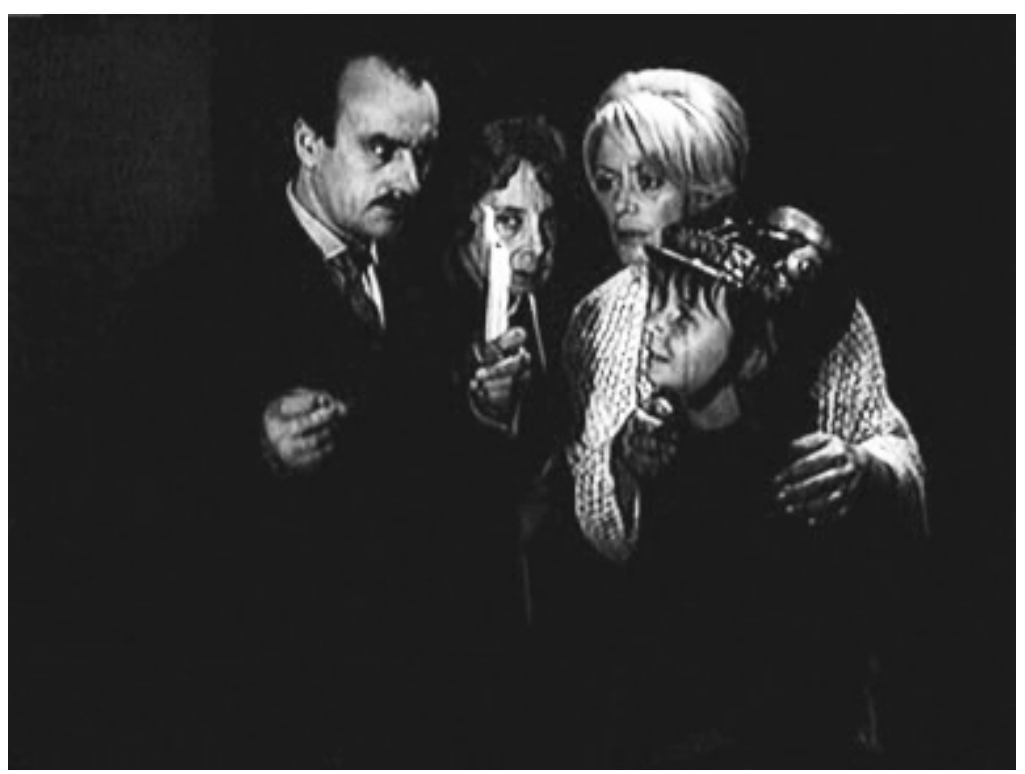

MB: Może po prostu nie rozumieli Twojej twórczości?

SG: Część krytyków uznała ją za niezdrową, mianowicie „neurasteniczną”, kto wie? - może wprost szkodliwą. A więc? Precz z nim! Niechaj nie mąci spokojnych i ustałych wód! Nam bowiem trzeba literatury „zdrowej”, dużo, dużo słońca i śmiechu. Więc śmiejmy się i weselmy, bo życie krótkie i należy go umieć używać. Śmiech jest zdrowy i potrzebny do trawienia! Śmiech jest objawem plemiennej siły! Niech więc żyje śmiech i swojscy wesołkowie! Niech nam błaznują i wywracają koziołki!

MB: Ty, jak rozumiem, nie chciałeś wywracać koziołków?

SG: Taki już sobie jestem. Na to nie poradzi. I może właśnie temu zawdzięczam swą odrębność, która nie wszystkim jest do smaku. Cóż robić!

Bywają i tacy widocznie potrzebni na tym szerokim, bożym świecie. Choćby na to, by jak semafor pośród nocy błysnąć od czasu do czasu ostrzegawczym sygnałem, choćby na to, by zaświadczyć o istnieniu nadzmysłowego rzeczy porządku ${ }^{15}$.

${ }^{15}$ Stacja Specjalna: Pośmiertny wywiad ze Stefanem Grabińskim, M. Budak, S. Grabiński, http://www.carpenoctem.pl/teksty/stacja-specjalna-posmiertny-wywiad-ze-stefanem-grabinskim [dostęp: 26.03.2012]. 


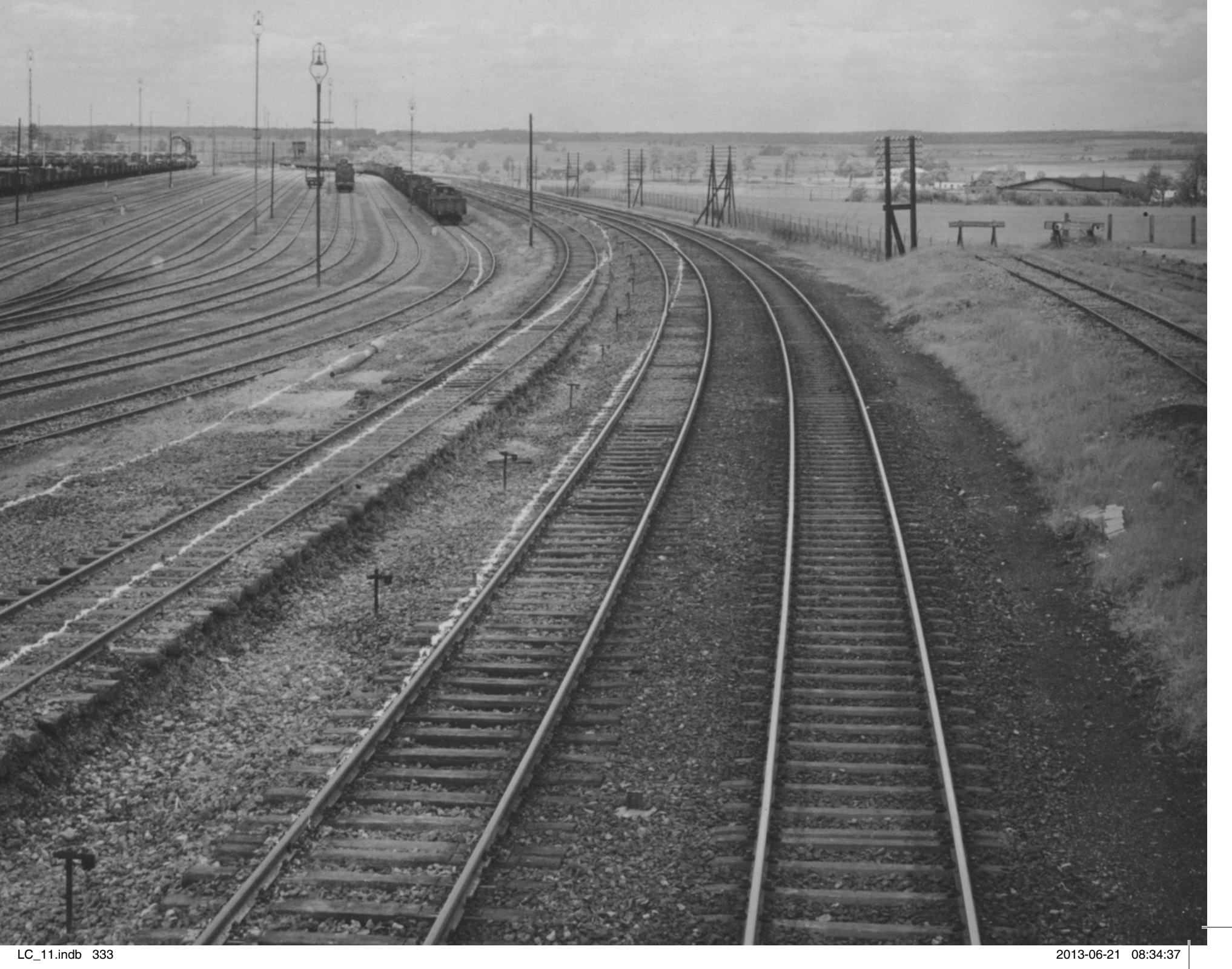

